\title{
DEPENDENCE ANALYSIS OF EXPORT- ORIENTED AND SECONDARY INDUSTRIES DEVELOPMENT IN RESOURCE-PRODUCING AREA
}

\author{
Evlanov E.A. \\ Yugra State University, \\ Khanty-Mansiysk, 628011, Russia
}

\author{
Islamutdinova D.F. \\ Yugra State University, \\ Khanty-Mansiysk, 628011, Russia
}

\author{
Islamutdinov V.F. \\ Yugra State University, \\ Khanty-Mansiysk, 628011, Russia
}

\author{
Ustyuzhantseva A.N. \\ Yugra State University, \\ Khanty-Mansiysk, 628011, Russia
}

\author{
Shubina V.I. \\ Yugra State University, \\ Khanty-Mansiysk, 628011, Russia
}

\begin{abstract}
The paper reflects research findings of the path dependence of export-oriented and secondary industries in the Khanty-Mansi Autonomous Okrug - Yugra by performing an autocorrelation analysis. In the export-oriented industries, a widespread dependence on last year's indicators and a negative internal cycle have been found. Development dependence analysis of secondary industries showed that development of the construction and manufacturing industries features a 4-year internal cycle with generally negative dependence, but in the agricultural industry, cyclicity of development has not been revealed due to the impact of such external factor as weather conditions. It has been revealed that the path dependence of industries in the Khanty-Mansi Autonomous Okrug - Yugra causes problems for economic reforming and diversification.
\end{abstract}

Keywords- Evolution of economic industries, resourceextraction region, export-oriented industries, secondary industries, autocorrelation analysis, path dependence.

\section{INTRODUCTION}

At present, studying a path dependence concept is becoming more relevant, which states that minor random events can set institutional development on an inefficient path [11]. Douglass North is believed to be the originator of this scientific direction, winning the 1993 Nobel Memorial Prize in Economic Sciences for his constructive application of the comparative institutional analysis in his works on economic history [16]. The current state of the institutional system depends on its development over previous periods, curbing freedoms of arbitrary choice, import or institution design and may lead to stabilizing inefficient institutional systems, or "institutional trap" [9]. This problem is basically considered in the context of Russia's economic development at large, but research to define development dependence of economic sectors in the northern resource-extraction region is still scarce.

The relevance of this study is that the region's economic development is determined not only by economic and technological factors, but by institutional ones as well. Institutional analysis is one of the most requested methodological approaches to study regional specifics, as it expands the object of regional analysis due to incorporating new phenomena and events into it, which never before have been the object of regional analysis, as well as it recognizes the existence of regional modern path dependence [3, 4]. This dependence is especially pressing in the Khanty-Mansi Autonomous Okrug - Yugra (hereinafter KMAO - Yugra), being highly dependent on resource extraction economy and global market environment for hydrocarbon commodities.

The objective is to address the following scientific problems: what development path of export-oriented and secondary industries in the Khanty-Mansi Autonomous Okrug was and how this path did affect their further development.

The potential for using the research findings to address applied problems involves a revealed degree of path dependence of the region's economic evolution, allowing one to define its development inertia and, accordingly, adjust the expected results from infrastructure and institutional reforms. 


\section{AUTOCORRELATION ANALYSIS METHOD AND PATH DEPENDENCE THEORY}

Autocorrelation is one of the basic methods to study trends and cyclic components of time series [17]. Time series data, in contrast to ordinary sample data, characterizes an object in question at different moments or periods of time, and an autocorrelation function shows autocorrelation dependence on a lag value [1], i.e. there is a dependence between historical data and future levels of time series [6].

A correlation coefficient value $r(\tau)$ defines how strong the statistical association is between levels of time series shifted by $t$ time units [13]. A time lag defines the order of autocorrelation coefficients [2]. (1):

The autocorrelation coefficient is calculated by the formula

$$
r(\tau)=\frac{(n-\tau) \sum_{t=1}^{n-\tau} y_{\tau} y_{t+\tau}-\sum_{t=1}^{n-\tau} y_{t} \sum_{t=1}^{n-\tau} y_{t+\tau}}{\sqrt{\left[(n-\tau) \sum_{t=1}^{n-\tau} y_{t^{2}}-\left(\sum_{t=1}^{n-\tau} y_{t}\right)^{2}\right]\left[(n-\tau) \sum_{t=1}^{n-\tau} y_{t+\tau}^{n}-\left(\sum_{t=1}^{n-\tau} y_{t+\tau}\right)^{2}\right]}}
$$

Autocorrelation is applied in various economic fields: for analyzing stock markets [6], for determining return of credit institutions [7]. Also, the autocorrelation method is utilized in such scientific fields as microbiology to study relationships between chromosomes position and gene expression patterns [14], in medicine to detect spatial anomalies (hotspots) in regions of disease [18] etc. In this study, the autocorrelation method was employed to study path dependence of economic sectors in the resource-extraction region.

The theory of path dependence, in its turn, is also applied in many economic domains. Thus, Thomas Brekke pursues a study [12] on the regional path dependence theory affecting the industrial evolution in a non-migration region characterized by a specialized cluster of high-tech companies. Path dependence is reflected in economic geography: regional development prospects are directly related to historical dynamics of economic landscapes, i.e. they are "place-depend" [15]. Russian scientists [8] apply this theory to analyze the potential for the regional construction development in postSoviet states, as well as to assess its impact on the national economic growth strategy [10].

\section{ANALYSIS OF THE PATH DEPENDENCE OF EXPORT-ORIENTED INDUSTRIES DEVELOPMENT IN THE NORTHERN RESOURCE- EXTRACTION REGION}

Focus on production and manufactured export is one of the top priority areas of economic development of the region and the country as a whole alike. The Khanty-Mansi Autonomous Okrug belongs to an export-oriented region, with export accounting for $95.6 \%$ of its total foreign trade turnover. The region exports mineral fuel, oil and refined products, timber, etc. Crude oil accounts for $99.4 \%$ of the total export volume. Therefore, oil and gas production is seen to be the main industry in the KMAO - Yugra.

The evolution of the industry in question is certainly affected by its past condition. A lot has changed since commercial production started in 1964 through the present day. If the reservoir pressure maintenance technology was not initially applied, now it is a widely used one.

Searching for industry development patterns, an autocorrelation analysis of industry key indicators was performed (Table 1).

TABLE I. AUTOCORRELATION COEFFICIENTS BY KEY INDICATORS FOR OIL AND GAS INDUSTRY

\begin{tabular}{|c|c|c|c|c|c|c|c|c|c|c|}
\hline \multirow[t]{2}{*}{ Indicator } & \multicolumn{5}{|c|}{$\begin{array}{c}\text { By absolute value of } \\
\text { indicator with a shift (lag) }\end{array}$} & \multicolumn{5}{|c|}{$\begin{array}{l}\text { By incremental value of } \\
\text { indicator with a shift (lag) }\end{array}$} \\
\hline & \begin{tabular}{|c|}
1 \\
year
\end{tabular} & \begin{tabular}{|c|}
2 \\
years \\
\end{tabular} & \begin{tabular}{|c|}
3 \\
years
\end{tabular} & \begin{tabular}{|c|}
4 \\
years
\end{tabular} & \begin{tabular}{|c|}
5 \\
years
\end{tabular} & \begin{tabular}{|c|} 
\\
year
\end{tabular} & \begin{tabular}{|c|}
2 \\
years
\end{tabular} & \begin{tabular}{|c|}
3 \\
years
\end{tabular} & \begin{tabular}{|c|}
4 \\
years
\end{tabular} & $\begin{array}{c}5 \\
\text { years }\end{array}$ \\
\hline Value added & 0,92 & 0,77 & 0,68 & 0,69 & 0,85 & 0,16 & $-0,37$ & $-0,21$ & $-0,49$ & 0,07 \\
\hline $\begin{array}{|ll|}\text { Number } & \text { of } \\
\text { enterprises }\end{array}$ & 0,95 & 0,95 & 0,89 & 0,83 & 0,86 & - & 0,38 & 0,10 & $-0,38$ & 0,46 \\
\hline $\begin{array}{ll}\text { Number } & \text { of } \\
\text { employed }\end{array}$ & 0,91 & 0,91 & 0,83 & 0,84 & 0,94 & $\begin{array}{l}- \\
0,54\end{array}$ & 0,26 & $-0,38$ & 0,20 & 0,42 \\
\hline $\begin{array}{l}\text { Fixed assets } \\
\text { costs }\end{array}$ & 0,99 & 0,98 & 0,99 & 0,99 & 0,97 & 0,20 & $-0,03$ & 0,26 & 0,56 & 0,14 \\
\hline $\begin{array}{l}\text { Wear degree of } \\
\text { fixed assets }\end{array}$ & 0,87 & 0,60 & 0,14 & $-0,28$ & $-0,66$ & 0,24 & 0,08 & 0,27 & 0,07 & $-0,07$ \\
\hline $\begin{array}{l}\text { Industry } \\
\text { enterprises } \\
\text { turnover }\end{array}$ & 0,94 & 0,87 & 0,87 & 0,91 & 0,88 & - & $-0,46$ & $-0,10$ & 0,28 & 0,12 \\
\hline $\begin{array}{l}\text { Shipping } \\
\text { volume }\end{array}$ & 0,98 & 0,94 & 0,93 & 0,95 & 0,97 & 0,08 & $-0,60$ & $-0,23$ & 0,51 & 0,52 \\
\hline $\begin{array}{l}\text { Industrial } \\
\text { production } \\
\text { index }\end{array}$ & $-\overline{-}$ & $-0,57$ & 0,19 & 0,39 & $-0,29$ & $-\overline{0}, 28$ & $-0,56$ & 0,25 & 0,36 & $-0,68$ \\
\hline Price index & \begin{tabular}{|l|l|}
- \\
0,69 \\
\end{tabular} & 0,57 & $-0,44$ & 0,20 & $-0,54$ & - & 0,39 & $-0,36$ & 0,35 & $-0,70$ \\
\hline Import & \begin{tabular}{|l|l|}
- \\
0,27 \\
\end{tabular} & $-0,49$ & 0,13 & 0,00 & $-0,15$ & $\begin{array}{l} \\
0,37 \\
\end{array}$ & $-0,01$ & 0,12 & 0,03 & 0,06 \\
\hline Export & 0,18 & $-0,29$ & $-0,41$ & 0,13 & 0,55 & \begin{tabular}{l|l|}
- \\
0,09
\end{tabular} & 0,06 & $-0,16$ & $-0,13$ & 0,39 \\
\hline Gain, loss & 0,67 & 0,51 & 0,43 & 0,02 & $-0,09$ & $\begin{array}{l} \\
0,43 \\
\end{array}$ & $-0,19$ & 0,26 & $-0,62$ & 0,46 \\
\hline $\begin{array}{ll}\text { Proportion of } \\
\text { unprofitable } \\
\text { enterprises }\end{array}$ & 0,44 & 0,24 & 0,50 & 0,22 & 0,70 & 0,37 & $-0,20$ & 0,27 & $-0,52$ & 0,39 \\
\hline \begin{tabular}{ll|}
$\begin{array}{l}\text { Return } \\
\text { products }\end{array}$ & on \\
\end{tabular} & 0,65 & 0,69 & 0,18 & 0,69 & 0,49 & - & 0,22 & $-0,22$ & 0,08 & $-0,38$ \\
\hline Investments & 0,96 & 0,93 & 0,95 & 0,97 & 0,92 & 0,26 & $-0,09$ & $-0,06$ & 0,37 & 0,59 \\
\hline $\begin{array}{l}\begin{array}{l}\text { Labour } \\
\text { efficiency in } \\
\text { comparable } \\
2015 \text { prices }\end{array} \\
\end{array}$ & 0,36 & 0,52 & 0,33 & 0,31 & $-0,09$ & $-\overline{0}, 62$ & 0,14 & 0,06 & $-0,11$ & $-0,50$ \\
\hline $\begin{array}{l}\text { Number of } \\
\text { coefficients } \\
\text { with a value } \\
\text { greater than } 0.5\end{array}$ & 11 & 13 & 7 & 8 & 11 & 4 & 2 & 0 & 2 & 5 \\
\hline
\end{tabular}

Tending to 1 and significant autocorrelation coefficients have been found in the datasets in 2005-2015 for absolute value indicators "Value Added", "Number of Enterprises", "Fixed Assets Costs", "Wear Degree of Fixed Assets", "Enterprise Turnover", "Price Index", "Enterprise Gain, Loss", "Return on Products", "Investments" revealed [13]. Moreover, for the datasets "Number of Employees", "Price Index", "Return on Products", tendencies have also been found in relative values, which indicates the presence of linear dependence in these indicators change over time.

As for the changes in indicators by relative values, wherein tending to 1 with significant autocorrelation coefficients is 
evident, they are somewhat less: "Number of Employed", "Price Index", "Return on Products", "Labour Efficiency".

In some indicators, periodic fluctuations with a 5-year lag have been found. However, given the relatively short period in question concerning the shift, these fluctuations are not considered. With that said, periodic patterns with a different lag value have been found for the following datasets: "Return on Products" with a second-degree lag in absolute values, and "Labour Efficiency in comparable prices of 2015" with a second-degree lag in absolute values, as well as "Industrial Production Index" with a second-degree lag for datasets with absolute and relative values what indicates fluctuations with a two-year cycle.

Periodic fluctuations have been also observed for the dataset "Fixed Assets Costs" with a 4-year lag, both in absolute and relative values, which may be due to the reassessment period of fixed assets of industrial enterprises and investment activity, as the dataset "Investments" also has periodic fluctuations with a lag 4 .

The most numerous autocorrelation coefficients with a value greater than 0.5 have been obtained for a lag 2 , which suggests that there is a two-year cycle in the industry.

In addition to oil production, the Khanty-Mansi Autonomous Okrug is also the leader in terms of electric power production, with $20 \%$ being exported to other regions of the Russian Federation, and $70 \%$ of domestic consumption accounting for oil production. Consequently, it seems to be important analyzing the path dependence of the electric power industry (Table 2).

TABLE II. AUTOCORRELATION COEFFICIENTS BY KEY INDICATORS FOR THE ELECTRIC POWER INDUSTRY

\begin{tabular}{|c|c|c|c|c|c|c|c|c|c|c|}
\hline \multirow[t]{2}{*}{ Indicators } & \multicolumn{5}{|c|}{$\begin{array}{c}\text { By absolute value of } \\
\text { indicator with a shift (lag) }\end{array}$} & \multicolumn{5}{|c|}{$\begin{array}{l}\text { By incremental value of } \\
\text { indicator with a shift (lag) }\end{array}$} \\
\hline & $\begin{array}{c}1 \\
\text { year }\end{array}$ & \begin{tabular}{|c|}
2 \\
years
\end{tabular} & \begin{tabular}{|c|}
3 \\
years
\end{tabular} & \begin{tabular}{|c|}
4 \\
years
\end{tabular} & \begin{tabular}{|c|}
5 \\
years
\end{tabular} & \begin{tabular}{|c|}
1 \\
year
\end{tabular} & \begin{tabular}{|c|}
2 \\
years
\end{tabular} & \begin{tabular}{|c|}
3 \\
years
\end{tabular} & $\begin{array}{c}4 \\
\text { years }\end{array}$ & $\begin{array}{c}5 \\
5 \\
\text { years }\end{array}$ \\
\hline Value added & 0,95 & 0,83 & 0,79 & 0,66 & 0,53 & 0,15 & $-0,05$ & $-0,25$ & $-0,45$ & $-0,58$ \\
\hline $\begin{array}{ll}\text { Number } & \text { of } \\
\text { enterprises } & \end{array}$ & 0,56 & 0,03 & $-0,63$ & $-0,94$ & $-0,61$ & 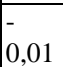 & $-0,03$ & $-0,03$ & $-0,99$ & 0,12 \\
\hline $\begin{array}{ll}\begin{array}{l}\text { Number } \\
\text { employed }\end{array} & \text { of } \\
\end{array}$ & 0,71 & 0,34 & 0,02 & $-0,40$ & $-0,94$ & 0,31 & $-0,29$ & $-0,23$ & 0,07 & $-0,80$ \\
\hline $\begin{array}{l}\text { Fixed assets } \\
\text { costs }\end{array}$ & 0,99 & 0,96 & 0,94 & 0,90 & 0,90 & 0,65 & 0,40 & 0,18 & $-0,47$ & $-0,61$ \\
\hline $\begin{array}{l}\text { Wear degree of } \\
\text { fixed assets }\end{array}$ & 0,71 & 0,57 & $-0,34$ & $-0,40$ & $-0,46$ & 0,32 & 0,46 & $-0,54$ & 0,12 & $-0,30$ \\
\hline $\begin{array}{l}\text { Industrial } \\
\text { production } \\
\text { index }\end{array}$ & - & $-0,33$ & 0,49 & $-0,04$ & $-0,31$ & $\overline{-}-27$ & $-0,52$ & 0,53 & 0,06 & $-0,26$ \\
\hline Investments & 0,79 & 0,43 & 0,11 & $-0,12$ & $-0,38$ & 0,24 & $-0,19$ & $-0,37$ & $-0,19$ & $-0,49$ \\
\hline Export & 0,59 & 0,03 & $-0,33$ & $-0,35$ & $-0,57$ & 0,06 & $-0,25$ & $-0,35$ & 0,01 & 0,03 \\
\hline Financial result & 0,96 & 0,87 & 0,77 & 0,65 & 0,49 & 0,41 & $-0,05$ & $-0,07$ & $-0,61$ & $-0,82$ \\
\hline Rate of return & 0,71 & 0,47 & 0,31 & $-0,03$ & $-0,40$ & 0,00 & $-0,28$ & $-0,15$ & $-0,30$ & $-0,28$ \\
\hline $\begin{array}{l}\text { Total number } \\
\text { of coefficients } \\
\text { with a value } \\
\text { greater than } 0.5\end{array}$ & 9 & 4 & 4 & 4 & 5 & 1 & 2 & 2 & 2 & 4 \\
\hline
\end{tabular}

The indicators "Value Added", "Fixed Assets Costs" and "Financial Result" have the highest values of autocorrelation with the past years, therefore, they are characterized by path dependence, and their changing from year to year is very slight.

Negative path dependence is traced in the indicators "Number of Enterprises" and "Number of Employed" with a time lag of over 2 years.

By absolute values, the most numerous coefficients with a value greater than 0.5 (i.e strong relation) account for a 1-year time lag. By incremental value, the most numerous coefficients account for a 5-year time lag, and most of them are negative. Therefore, a quite widespread dependence on last year's indicators and a 5-year negative internal cycle are observed in the electric power industry development.

\section{ANALYSIS OF THE PATH DEPENDENCE OF SECONDARY INDUSTRIES IN THE NORTHERN RESOURCE-EXTRACTION REGION}

Certain industries play a supporting role due to development peculiarities of productive forces and environmental conditions of the region. In the KMAO Yugra, such industries include construction, mechanical engineering and metalworking (considered within the "manufacturing" group of industries) and agriculture.

Also, an autocorrelation analysis of the indicators was performed to determine the degree of path dependence of the construction industry evolution (Table 3 ).

TABLE III. AUTOCORRELATION COEFFICIENTS BY KEY INDICATORS FOR THE CONSTRUCTION INDUSTRY

\begin{tabular}{|c|c|c|c|c|c|c|c|c|c|c|}
\hline \multirow[t]{2}{*}{ Indicators } & \multicolumn{5}{|c|}{$\begin{array}{c}\text { By absolute value of } \\
\text { indicator with a shift (lag) }\end{array}$} & \multicolumn{5}{|c|}{$\begin{array}{l}\text { By incremental value of } \\
\text { indicator with a shift (lag) }\end{array}$} \\
\hline & $\begin{array}{c}1 \\
\text { year }\end{array}$ & \begin{tabular}{|c|}
2 \\
years
\end{tabular} & $\begin{array}{c}3 \\
\text { years }\end{array}$ & \begin{tabular}{|c|}
4 \\
years
\end{tabular} & \begin{tabular}{|c|}
5 \\
years
\end{tabular} & $\begin{array}{c}1 \\
\text { year }\end{array}$ & \begin{tabular}{|c|}
2 \\
years \\
\end{tabular} & \begin{tabular}{|c|}
3 \\
years \\
\end{tabular} & \begin{tabular}{|c|}
4 \\
years
\end{tabular} & \begin{tabular}{|c|}
5 \\
years \\
\end{tabular} \\
\hline Value added & $-\overline{0}$ & $-0,82$ & $-0,22$ & 0,63 & 0,64 & 0,57 & $-0,70$ & $-0,51$ & $-0,07$ & $-0,35$ \\
\hline $\begin{array}{ll}\begin{array}{l}\text { Number } \\
\text { enterprises }\end{array} & \text { of } \\
\end{array}$ & 0,02 & $-0,66$ & $-0,88$ & $-0,30$ & 0,26 & 0,39 & $-0,76$ & $-0,73$ & 0,45 & 0,59 \\
\hline $\begin{array}{l}\text { Number } \quad \text { of } \\
\text { employed }\end{array}$ & 0,49 & 0,01 & $-0,63$ & $-0,70$ & $-0,17$ & 0,75 & $-0,02$ & $-0,76$ & $-0,52$ & 0,01 \\
\hline $\begin{array}{l}\text { Fixed assets } \\
\text { costs }\end{array}$ & 0,97 & 0,92 & 0,87 & 0,85 & 0,88 & 0,63 & $-0,16$ & $-0,03$ & $-0,48$ & $-0,33$ \\
\hline $\begin{array}{l}\text { Wear degree of } \\
\text { fixed assets }\end{array}$ & - & 0,01 & 0,76 & 0,89 & 0,91 & $0,-5$ & $-0,28$ & 0,38 & 0,25 & $-0,51$ \\
\hline $\begin{array}{l}\text { Industry } \\
\text { products price } \\
\text { index }\end{array}$ & 0,46 & 0,39 & $-0,60$ & $-0,66$ & 0,44 & 0,45 & 0,57 & $-0,57$ & $-0,43$ & 0,24 \\
\hline $\begin{array}{l}\text { Fixed } \\
\text { investment }\end{array}$ & 0,80 & $-0,13$ & 0,04 & $-0,16$ & $-0,69$ & 0,79 & $-0,50$ & 0,17 & 0,36 & $-0,71$ \\
\hline $\begin{array}{l}\text { New housing } \\
\text { supply }\end{array}$ & 0,63 & $-0,27$ & $-0,40$ & $-0,05$ & 0,54 & 0,91 & $-0,19$ & $-0,42$ & $-0,55$ & $-0,20$ \\
\hline Gain, loss & 0,20 & 0,20 & $-0,82$ & $-0,21$ & $-0,19$ & 0,24 & 0,56 & $-0,79$ & $-0,01$ & $-0,49$ \\
\hline $\begin{array}{l}\text { Proportion of } \\
\text { unprofitable } \\
\text { enterprises }\end{array}$ & 0,50 & $-0,26$ & $-0,41$ & $-0,17$ & $-0,48$ & 0,35 & $-0,54$ & $-0,22$ & 0,25 & $-0,60$ \\
\hline $\begin{array}{l}\text { Total number } \\
\text { of coefficients } \\
\text { with a value } \\
\text { greater than } 0.5\end{array}$ & 4 & 3 & 6 & 5 & 3 & 5 & 4 & 5 & 2 & 3 \\
\hline
\end{tabular}

c. Sources: (Rosstat, 2005-2015) and authors' calculations.

The indicator "Industry's Fixed Assets Costs at the YearEnd" has very high autocorrelation coefficients with the past 
years, i.e. this indicator is characterized by path dependence and varies from year to year very slightly.

The most numerous autocorrelation coefficients with a value greater than 0.5 in absolute values account for a 3 -year time lag, which indicates a quite strong relation, however, the dependence is predominantly negative. This means the presence of reverse relation: the higher the value in one year, the lower the value in the other. This relationship is observed for such indicators as "Number of Enterprises", "Number of Employed", "Industry Products Price Index", "Balanced Financial Result (Gain, Loss)." That is, a 3-year cycle takes place in the industry development.

Given that the "Mechanical Engineering and Metalworking" industry is of a derived nature in KMAO Yugra, mainly from the oil production industry, the fact that the industry indicators in the past influence its performance in the future is not called for [5]. Clearly, part of revenues can be put in production expansion and investment, but this is most likely due to the increase in order volume on the part of oil companies. We have calculated autocorrelation coefficients (Table 4) to comprehend the degree of path dependence of the manufacturing industry.

TABLE IV. AUTOCORRELATION COEFFICIENTS BY KEY INDICATORS FOR THE MANUFACTURING INDUSTRY

\begin{tabular}{|c|c|c|c|c|c|c|c|c|c|c|}
\hline \multirow[t]{2}{*}{ Indicators } & \multicolumn{5}{|c|}{$\begin{array}{c}\text { By absolute value of } \\
\text { indicator with a shift (lag) }\end{array}$} & \multicolumn{5}{|c|}{$\begin{array}{l}\text { By incremental value of } \\
\text { indicator with a shift (lag) }\end{array}$} \\
\hline & \begin{tabular}{|c|}
1 \\
year
\end{tabular} & $\begin{array}{c}2 \\
\text { years }\end{array}$ & \begin{tabular}{|c|}
3 \\
years
\end{tabular} & $\begin{array}{c}4 \\
\text { years }\end{array}$ & \begin{tabular}{|c|}
5 \\
years
\end{tabular} & $\begin{array}{c} \\
\text { year }\end{array} \mid$ & \begin{tabular}{|c|}
2 \\
years
\end{tabular} & $\begin{array}{c}3 \\
\text { years }\end{array}$ & \begin{tabular}{|c|}
4 \\
years
\end{tabular} & $\begin{array}{c}5 \\
5 \\
\text { years }\end{array}$ \\
\hline Value added & 0,05 & 0,17 & $-0,52$ & $-0,71$ & $-0,19$ & \begin{tabular}{|l|}
- \\
0,58
\end{tabular} & 0,49 & $-0,21$ & $-0,78$ & 0,32 \\
\hline $\begin{array}{ll}\begin{array}{l}\text { Number } \\
\text { enterprises }\end{array} & \text { of }\end{array}$ & 0,82 & 0,81 & 0,63 & 0,37 & $-0,24$ & $\begin{array}{l}- \\
0,32\end{array}$ & 0,36 & $-0,14$ & 0,45 & $-0,31$ \\
\hline $\begin{array}{l}\text { Number } \\
\text { employed }\end{array}$ & 0,90 & 0,95 & 0,92 & 0,72 & 0,72 & \begin{tabular}{l|l|}
- \\
0,50
\end{tabular} & 0,02 & 0,55 & $-0,95$ & 0,21 \\
\hline $\begin{array}{l}\text { Fixed assets } \\
\text { costs }\end{array}$ & 0,68 & 0,07 & 0,66 & 0,81 & 0,92 & \begin{tabular}{|l|l|}
- & \\
0,13
\end{tabular} & $-0,87$ & 0,50 & $-0,47$ & 0,88 \\
\hline $\begin{array}{l}\text { Wear degree of } \\
\text { fixed assets }\end{array}$ & 0,65 & 0,23 & 0,54 & 0,63 & $-0,42$ & 0,09 & $-0,95$ & $-0,18$ & 0,39 & $-0,07$ \\
\hline $\begin{array}{l}\text { Industrial } \\
\text { production } \\
\text { index }\end{array}$ & 0,08 & $-0,48$ & 0,29 & 0,61 & 0,08 & $-\overline{0}$ & $-0,64$ & $-0,15$ & 0,50 & $-0,03$ \\
\hline Investments & 0,59 & 0,30 & $-0,42$ & 0,20 & 0,76 & - & $-0,37$ & $-0,97$ & $-0,16$ & 0,35 \\
\hline Export & 0,41 & $-0,09$ & 0,06 & $-0,03$ & 0,72 & 0,10 & $-0,29$ & 0,11 & $-0,63$ & 0,17 \\
\hline Gain, loss & 0,37 & $-0,14$ & $-0,29$ & $-0,47$ & $-0,40$ & 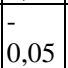 & $-0,24$ & 0,06 & $-0,17$ & $-0,30$ \\
\hline Rate of return & 0,46 & 0,13 & $-0,52$ & $-0,91$ & $-0,28$ & - & 0,16 & $-0,09$ & $-0,82$ & 0,56 \\
\hline $\begin{array}{l}\text { Total number } \\
\text { of coefficients } \\
\text { with a value } \\
\text { greater than } 0.5\end{array}$ & 5 & 2 & 4 & 6 & 4 & 2 & 3 & 3 & 4 & 2 \\
\hline
\end{tabular}

The indicators "Number of Employed" and "Number of Enterprises" have quite high autocorrelation coefficients with the past years, accordingly, these indicators are path dependent and vary from year to year very slightly.

The most numerous autocorrelation coefficients with a value greater than 0.5 , both in absolute values and increment, account for a 4-year time lag, which indicates the relation is strong enough. It should be noted that the dependence is mostly negative, i.e. high 4-year-old indicators result in current low indicators. In particular, this fact can be observed in such indicators as "Rate of Return", "Value Added", and less explicitly, "Number of Employed" and "Fixed Assets Costs". Thus, based on the correlation coefficients calculations, we can argue there is a 4-year internal cycle in the manufacturing industry development [5].

Agriculture belongs to secondary industries in the KhantyMansi Autonomous Okrug as well. Adverse environmental conditions within the northern territories are the reason for a low biological productivity of farmlands in the autonomous okrug, therefore it is meat-and-dairy cattle farming, fish farming, fur farming, reindeer herding and olericulture that make the basis for the region's agriculture. Autocorrelation coefficients calculation of the agriculture's path dependence is presented in Table 5.

TABLE V. AUTOCORRELATION COEFFICIENTS BY KEY INDICATORS FOR AGRICULTURAL INDUSTRY

\begin{tabular}{|c|c|c|c|c|c|c|c|c|c|c|}
\hline \multirow[t]{2}{*}{ Indicators } & \multicolumn{5}{|c|}{$\begin{array}{c}\text { By absolute value of indicator } \\
\text { with a shift (lag) }\end{array}$} & \multicolumn{5}{|c|}{$\begin{array}{l}\text { By incremental value of } \\
\text { indicator with a shift (lag) }\end{array}$} \\
\hline & $\begin{array}{c}1 \\
\text { year }\end{array}$ & \begin{tabular}{|c|}
2 \\
years
\end{tabular} & \begin{tabular}{|c|}
3 \\
years
\end{tabular} & \begin{tabular}{|c|}
4 \\
years
\end{tabular} & \begin{tabular}{|c|}
5 \\
years
\end{tabular} & \begin{tabular}{|c|}
1 \\
year
\end{tabular} & \begin{tabular}{|c|}
2 \\
years
\end{tabular} & \begin{tabular}{|c|}
3 \\
years
\end{tabular} & \begin{tabular}{|c|}
4 \\
years
\end{tabular} & \begin{tabular}{|c|c|}
5 \\
years
\end{tabular} \\
\hline Value added & 0 & 0.63 & -0.31 & -0.31 & -0.31 & - & - & - & - & - \\
\hline $\begin{array}{ll}\text { Number } & \text { of } \\
\text { enterprises } & \end{array}$ & 0.35 & 0.34 & 0.36 & 0.62 & 0.48 & 0.23 & 0.09 & -0.27 & 0.83 & -0.44 \\
\hline $\begin{array}{ll}\text { Number } & \text { of } \\
\text { employed }\end{array}$ & 0.79 & 0.41 & 0.67 & 0.61 & 0.72 & 0.03 & -0.70 & 0.57 & 0.09 & 0.22 \\
\hline $\begin{array}{ll}\text { Fixed assets } \\
\text { costs }\end{array}$ & 0.996 & 0.998 & 0.994 & 0.991 & 0.987 & 0.62 & 0.65 & -0.13 & 0.22 & 0.23 \\
\hline $\begin{array}{l}\text { Wear degree of } \\
\text { fixed assets }\end{array}$ & 0.14 & -0.91 & -0.26 & 0.05 & 0.02 & \begin{tabular}{|l|}
- \\
0.09 \\
\end{tabular} & -0.48 & -0.04 & 0.25 & 0.47 \\
\hline $\begin{array}{l}\text { Agricultural } \\
\text { production } \\
\text { index }\end{array}$ & -0.45 & -0.07 & 0.08 & -0.35 & 0.34 & $-\overline{0}$ & 0.20 & 0.12 & -0.38 & 0.39 \\
\hline Investments & -0.13 & -0.18 & -0.29 & -0.15 & -0.15 & \begin{tabular}{|l|l|}
- \\
0.50 \\
\end{tabular} & 0.33 & -0.37 & -0.16 & -0.04 \\
\hline Export & -0.24 & -0.29 & -0.38 & 0.23 & 0.25 & \begin{tabular}{l|l|}
- \\
0.49 \\
\end{tabular} & 0.01 & -0.49 & 0.39 & -0.01 \\
\hline $\begin{array}{l}\text { Gain, loss - } \\
\text { crop farming }\end{array}$ & -0.09 & -0.37 & 0.45 & 0.35 & -0.10 & $\begin{array}{l}- \\
0.35 \\
\end{array}$ & -0.33 & 0.56 & 0.04 & 0.21 \\
\hline $\begin{array}{l}\text { Gain, loss }- \\
\text { cattle farming }\end{array}$ & -0.23 & -0.46 & -0.02 & -0.24 & 0.75 & $\begin{array}{l}-59 \\
\end{array}$ & 0.38 & 0.09 & -0.66 & 0.88 \\
\hline $\begin{array}{l}\text { Return on crop } \\
\text { farming }\end{array}$ & 0.82 & 0.87 & 0.49 & 0.65 & -0.08 & $-\overline{0}-54$ & 0.15 & 0.34 & -0.60 & 0.83 \\
\hline $\begin{array}{l}\text { Return on } \\
\text { cattle farming }\end{array}$ & -0.35 & -0.43 & 0.53 & 0.17 & -0.80 & \begin{tabular}{|l|}
- \\
0.44 \\
\end{tabular} & -0.18 & 0.32 & 0.49 & -0.74 \\
\hline $\begin{array}{l}\text { Total number } \\
\text { of coefficients } \\
\text { with a value } \\
\text { greater than } 0.5\end{array}$ & 3 & 4 & 3 & 4 & 3 & 5 & 1 & 2 & 3 & 2 \\
\hline
\end{tabular}

Table 5 shows no stable relation either in absolute or in increment values. Identifying the cyclicality in this industry is seen to be very difficult due to such external factor, as weather conditions.

\section{CONCLUSIONS}

The autocorrelation coefficients analysis has showed that path dependence is present in most industries. And there is a cyclical development in some industries. For instance, oil and gas production has a 3-year cycle. A 5-year cycle is traced in the electric power industry development. A 4-year internal 
cycle is evident in the manufacturing industry development, including the mechanical engineering and metalworking industry. A 3-year cycle is observed in the construction industry. In contrast, there is no evident cyclicity in such industries as agriculture and fish farming.

Analyzing groups of industries, we can argue the exportoriented industries have a negative internal development cycle. The indicators "Value Added", "Fixed Assets Costs" and "Financial Result" have the highest values of autocorrelation with the past years, however, the cyclicality level in the industries differ markedly. Secondary industries have a 4-year development cycle, and the dependence is mostly negative, that is, high 4-year-old indicators result in low current indicators, except for the agricultural sector, which is affected by the uncontrolled factor (environmental conditions).

Thus, the paper summarizes the analysis results of the degree of path-dependent economic industries evolution in the northern resource-extraction region. The authors have revealed the Khanty-Mansi Autonomous Okrug is more of a pathdependent region, posing problems for economic reforming and diversification. Accordingly, it is theoretically and practically significant to further research factors affecting the economic sectors development in the northern resourceextraction region, consider correlation dependencies between them, as well as predict key development indicators.

\section{Acknowledgment}

The research was conducted with funding from the Russian Foundation for Basic Research and the Department of Education and Science of the Khanty-Mansi Autonomous Okrug-Yugra, grant No. 17-12-86010 "Long-term forecasting of the economic evolution of the resource-extraction region, considering path-dependence and institutional environment features (case study of the Khanty-Mansi Autonomous Okrug - Yugra)".

\section{References}

[1] M. P. Bazilevsky, G. D. Gefan, On autocorrelation effects consideration in time series, Information technologies and complex systems mathematical modeling issues, 2015, pp. 11-22.

[2] D. Y. Zhmurko, Applying correlation analysis in the sugar agroindustrial business (part 1 - autocorrelation and partial autocorrelation), Multidisciplinary Networked Electronic Journal of Kuban State Agrarian University, 2016, No. 116, p. 1073-1109.

[3] V. F. Islamutdinov, Comparative institutional analysis as a new method to study regional specific features, Bulletin of Yugra State University, 2015, No. S4 (39), p. 308-312.

[4] V. F. Islamutdinov, Evolution and specificity of the economic institutions of Khanty-Mansi Autonomous Okrug - Yugra, Economy of Region, 2016, no. 12, issue 2, pp. 463-470.

[5] V. F. Islamutdinov, Studying the evolution and institutional environment for the Mechanical Engineering and Metalworking industrial development in the Khanty-Mansi Autonomous Okrug - Yugra, Economics and Management, 2017, No. 11, p. 34-46.

[6] N. V. Katargin, A. V. Tsvetkov, Studying high-order autocorrelations in series of asset prices on the stock market, International Science Journal, 2011, No. 4, p. 38-42.
[7] E. R. Kerimova, Econometric cost-benefit analysis of credit institutions, Science and Education: Economy and Economics, Entrepreneurship; Law and Management, 2011, No. 5 (11), pp. 62-68.

[8] V. E. Korolkov, E. L. Moreva, The domino theory and path dependence development: opportunities and limitations in the post-Soviet states, Advances in modern science and education, 2016, No. 10, p. 78-83.

[9] A. M. Libman, Optimal path dependence, Social sciences and modernity, 2008, No. 5, pp. 5-17.

[10] I. Rudakova, The National Strategy of Economic Growth: Path Dependence and Milestones, Bulletin of the Institute of Economics, Russian Academy of Sciences, 2013, No. 4, pp. 26-38.

[11] I. M. Shiryaev, Path dependence development and path establishing as the most important concepts in the evolutionary economics, Journal of Economic Regulation, 2013, vol. 4, No. 3, p. 103-112.

[12] T. Brekke, Regional economic change, entrepreneurship and regional path dependency in Non-Metropolitan Region, 2015. Access mode: http://www.regionalstudies.org/uploads/Thomas_Brekke.pdf

[13] T. Cooley, M. Ogaki, A Time Series Analysis of Real Wages, Consumption, and Asset Returns, Journal of Applied Econometrics, 1996, Vol. 11, No. 2, 119-134.

[14] A. Koren, I. Tirosh, N. Barkai, Autocorrelation analysis reveals widespread spatial biases in microarray experiments, BMC Genomics, $2007 . \quad$ Access mode: https://bmcgenomics.biomedcentral.com/articles/10.1186/1471-2164-8164

[15] R. Martin, P. Sunley, Path dependence and regional economic evolution, Journal of Economic Geography, 2006, no. 6, № 4, pp. 395-437.

[16] D. North, J.J. Wallis, S.E. Webb, Weingast B. Limited Access Orders in the Developing World: A New Approach to the Problems of Development, World Bank Policy Research Working Paper, 2007. Access mode: http://econweb.umd.edu/ wallis/MyPapers/Limted_Access_Orders_in_t he_Developing_WorldWPS4359.pdf

[17] A. Peters, Statistics for Analysis of Experimental Data. Champaign: AEESP, IL, 2001

[18] P.J. Tsai, M.L. Lin, C.M. Chu, C.H. Perng, Spatial autocorrelation analysis of health care hotspots in Taiwan in 2006, BMC Public Health, $2009 . \quad$ Access mode: https://bmcpublichealth.biomedcentral.com/articles/10.1186/1471-2458$9-464$ 